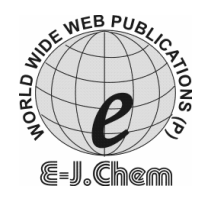

http://www.e-journals.net
ISSN: 0973-4945; CODEN ECJHAO

E-Journal of Chemistry

2009, 6(1), 93-98

\title{
Kinetics and Mechanism of Oxidation of $L$-Cystine by Hexacyanoferrate(III) in Alkaline Medium
}

\author{
ANNAPURNA NOWDURI, KALYAN KUMAR ADARI, \\ NAGESWARA RAO GOLLAPALLI and VANI PARVATANENI* \\ Department of Inorganic and Analytical Chemistry, \\ School of Chemistry, Andhra University, Visakhapatnam-530 003, India. \\ vani_chem@rediffmail.com
}

Received 20 March 2008; Accepted 10 May 2008

\begin{abstract}
Kinetics of oxidation of $L$-cystine by hexacyanoferrate(III) was studied in alkaline medium at $30^{\circ} \mathrm{C}$. The reaction was followed spectrophotometrically at $\lambda \max =420 \mathrm{~nm}$. The reaction was found to be first order dependence each on $[\mathrm{HCF}(\mathrm{III})]$ and [cystine]. It was found that the rate of the reaction increases with increase in $\left[\mathrm{OH}^{-}\right]$. The oxidation product of the reaction was found to be cysteic acid. A plausible mechanism has been proposed to account for the experimental results.
\end{abstract}

Keywords: Kinetics, Oxidation of $L$-cystine, Hexacyanoferrate(III).

\section{Introduction}

The kinetic investigations on the oxidation of amino acids become important because of their significance and selectivity towards the oxidants. $L$-cystine is a covalently linked dimeric non essential amino acid formed by oxidation of $L$-cysteine. The formation of disulfide bonds between two cysteine residues within proteins is important in the formation of active structural domains in a large number of proteins. Cystine is required for proper utilization of vitamin $\mathrm{B}_{6}$ and is also helpful in the healing of burns and wounds, breaking down mucus deposits in patients suffering from bronchitis and cystic fibrosis. The reduction capability of cystine is responsible for all these beneficiary effects where it acts as scavenger to the oxidants and free radicals in situ. In fact a precise understanding of the mechanism of such biological redox reactions is important as it helps to know the toxic effects of the metals and also to synthesise specific reaction products. The literature survey reveals that kinetic studies on the oxidation of $L$-cystine were limited, using oxidants like iodine ${ }^{1}$, alkaline permanganate ${ }^{2}$, potassium ferrate ${ }^{3}$, chlorite and chlorine dioxide ${ }^{4}$ and hypochlorous 
$\operatorname{acid}^{5}$. To have a further insight into it, we carried out kinetic investigations on the oxidation of $L$-cystine. In continuation to our earlier work ${ }^{6,7}$, we now report the oxidation of $L$-cystine by hexacyanoferrate(III)(HCF(III)) in alkaline medium.

Hexacyanoferrate(III) is a one electron oxidant with a redox potential of $+0.45 \mathrm{~V}$ of $\mathrm{Fe}(\mathrm{CN})_{6}{ }^{3-} / \mathrm{Fe}(\mathrm{CN})_{6}{ }^{4-}$ couple in alkaline medium. It is one equivalent oxidant leading to its reduction to hexacyanoferrate(II), a stable product. It has been successfully used to oxidize several substrates of both organic ${ }^{8-13}$ as well inorganic ${ }^{14-20}$. Thus in order to explore the mechanism of oxidation by hexacyanoferrate(III) in alkaline medium and to check the selectivity of $L$-cystine towards $\mathrm{HCF}$ (III) we have carried out kinetic investigation on the oxidation of $L$-cystine by $\mathrm{HCF}(\mathrm{III})$ in alkaline medium.

\section{Experimental}

A $0.05 \mathrm{~mol} \mathrm{dm}^{-3}$ solution of $L$-Cystine (Himedia) in $0.125 \mathrm{~mol} \mathrm{dm}^{-3} \mathrm{NaOH}$ was prepared afresh by dissolving in required volume of sodium hydroxide.

A $0.01 \mathrm{~mol} \mathrm{dm}^{-3}$ solution of hexacyanoferrate(III) (E.Merck) was prepared by dissolving the requisite amount of the salt in doubly distilled water. The solution was standardized by measuring the absorbance using Milton Roy UV-Visible 1201 spectrophotometer at $420 \mathrm{~nm}\left(\varepsilon=1060 \pm 50 \mathrm{dm}^{3} \mathrm{~mol}^{-1} \mathrm{~cm}^{-1}\right)$.

Hexacyanoferrate(II) solution was prepared by dissolving a known amount of $\mathrm{K}_{4}\left[\mathrm{Fe}(\mathrm{CN})_{6}\right]$ in water. Sodium hydroxide (E.Merck) and sodium perchlorate (E.Merck) were used to maintain $\left[\mathrm{OH}^{-}\right]$and ionic strength respectively.

\section{Kinetic Procedure}

Kinetic measurements were carried out at $30 \pm 0.1^{0} \mathrm{C}$ in $0.40 \mathrm{~mol} \mathrm{dm}{ }^{-3}$ alkaline medium under the conditions $\left[\mathrm{OH}^{-}\right] \gg$ $>$ cystine $]>[\mathrm{HCF}(\mathrm{III})]$. The progress of the reaction was followed by measuring the absorbance of $[\mathrm{HCF}(\mathrm{III})]$ at $420 \mathrm{~nm}$ using Milton Roy $1201 \mathrm{UV}$ - Visible Spectrophotometer with $1 \mathrm{~cm}$ glass cells. The temperature was kept constant using a Siskin Julabo $-\mathrm{V}$ constant temperature liquid circulatory bath. The rate constants were found to be reproducible within $\pm 4 \%$.

The product analysis was carried out chromatographically ${ }^{21}$. The chromatographic plate was spotted with the reaction product and it was saturated with vapours of phenol and then it was run in water saturated phenol. After the development of the chromatogram, the plate was removed from the tank and dried. It was then sprayed with $1 \%$ solution of ninhydrin in $n$-butanol and heated in an oven for five minutes at $100^{\circ} \mathrm{C}$. The $R_{f}$ value was found to be 0.16 for cysteic acid which was in good agreement with the value reported by Srivatsava ${ }^{21}$. The product was further confirmed by carrying out the microscopic study by transferring the reaction product to a dish and evaporated on a water bath at $60^{\circ} \mathrm{C}$. On condensation of the solution, almost colourless mass was obtained. The mass was dissolved in $40 \%$ dilute alcohol and was re-crystallized. The crystals obtained were viewed under microscope and compared with those reported earlier by Shinohara in the oxidation of cystine by iodine ${ }^{1}$. In Figure 1 the needle shaped crystals represent cysteic acid.

The test for free radicals was carried out taking cystine and $\mathrm{NaOH}$ in a thumberg tube and acrylonitrile, $\mathrm{HCF}$ (III) solution in a bent tube. After evacuating the system, the solutions were mixed by tilting the tube. The reaction mixture was kept aside and even after $24 \mathrm{~h}$ no precipitate was observed. 


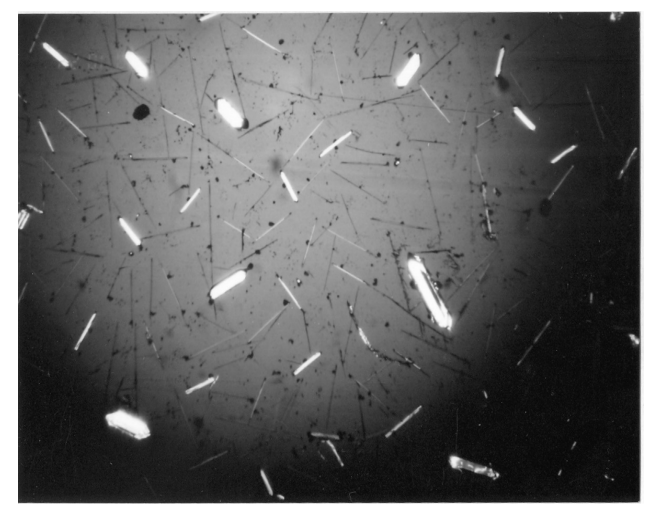

Figure 1. Cysteic acid crystals (needle shaped crystals).

\section{Results and Discussion}

Stoichiometry

The reaction mixture containing an excess [HCF(III)] over [cystine] at $0.4 \mathrm{~mol} \mathrm{dm}^{-3} \mathrm{NaOH}$ at constant ionic strength was allowed to react and after completion of the reaction, the amount of ferrate(II) formed (which is equal to the amount of ferrate(III) consumed) was determined by measuring the absorbance of the reaction mixture. It was observed that 10 moles of $\mathrm{HCF}$ (III) react with 1 mole of cystine as given by the equation.

\section{Reaction orders}

$$
\text { cystine }+10 \mathrm{HCF}(\mathrm{III}) \rightarrow 2 \text { cysteic acid }+10 \mathrm{HCF}(\mathrm{II})
$$

When the kinetic runs were made with isolation of $[\mathrm{HCF}(\mathrm{III})]$ by taking cystine in excess, plots of $\log$ (absorbance) versus time were found to be linear up to $85 \%$ completion of the reaction, indicating that the reaction is first order in $[\mathrm{HCF}(\mathrm{III})]$.

To find out the dependence of rate on [cystine], kinetic runs were carried out varying the [cystine], from 2.0 to $7.0 \times 10^{-3} \mathrm{~mol} \mathrm{dm}^{-3}$ keeping the concentration of all other species constant. The pseudo first order rate constants were found to be increased with increase in the concentration of cystine. Further, the plot of $\mathrm{k}^{\prime}$ versus [cystine] is a good straight line passing through origin indicating the order with respect to [cystine] to be one (Figure 2). In order to study the effect of $\left[\mathrm{OH}^{-}\right]$on the rate of the reaction, kinetic runs were carried out keeping the concentrations of all other reactants constant and varying $\left[\mathrm{OH}^{-}\right]$with sodium hydroxide from 0.2 to $0.7 \mathrm{~mol} \mathrm{dm}^{-3}$. The data presented in Table 1 show that the rate of the reaction increases with increase in $\left[\mathrm{OH}^{-}\right]$and the order with respect to $\left[\mathrm{OH}^{-}\right]$to be one (Figure 3).

\section{Effect of hexacyanoferrate(II)}

Kinetic runs were carried out keeping the concentrations of all other reactants constant, but varying the concentration of $\mathrm{HCF}$ (II) from 1.0 to $10.0 \times 10^{-4} \mathrm{~mol} \mathrm{dm}^{-3}$. It was observed that $\mathrm{HCF}(\mathrm{II})$, one of the products has no effect on the rate of reaction..

\section{Effect of ionic strength}

The effect of ionic strength on the rate of the reaction was studied by varying the ionic strength from 0.4 to $0.7 \mathrm{~mol} \mathrm{dm}{ }^{-3}$, using $\mathrm{NaClO}_{4}$ solution keeping the concentrations of all other reactants constant. It was found that ionic strength effect was negligible on the rate of the reaction.(Table 1). 
Table 1. Effect of varying concentrations of $[\mathrm{HCF}(\mathrm{III})]$, [cystine], $\left[\mathrm{OH}^{-}\right]$and $\left[\mathrm{NaClO}_{4}\right]$ on the pseudo first order rate constant, $\mathrm{k}^{\prime}$ at $30 \pm 0.1^{0} \mathrm{C}$

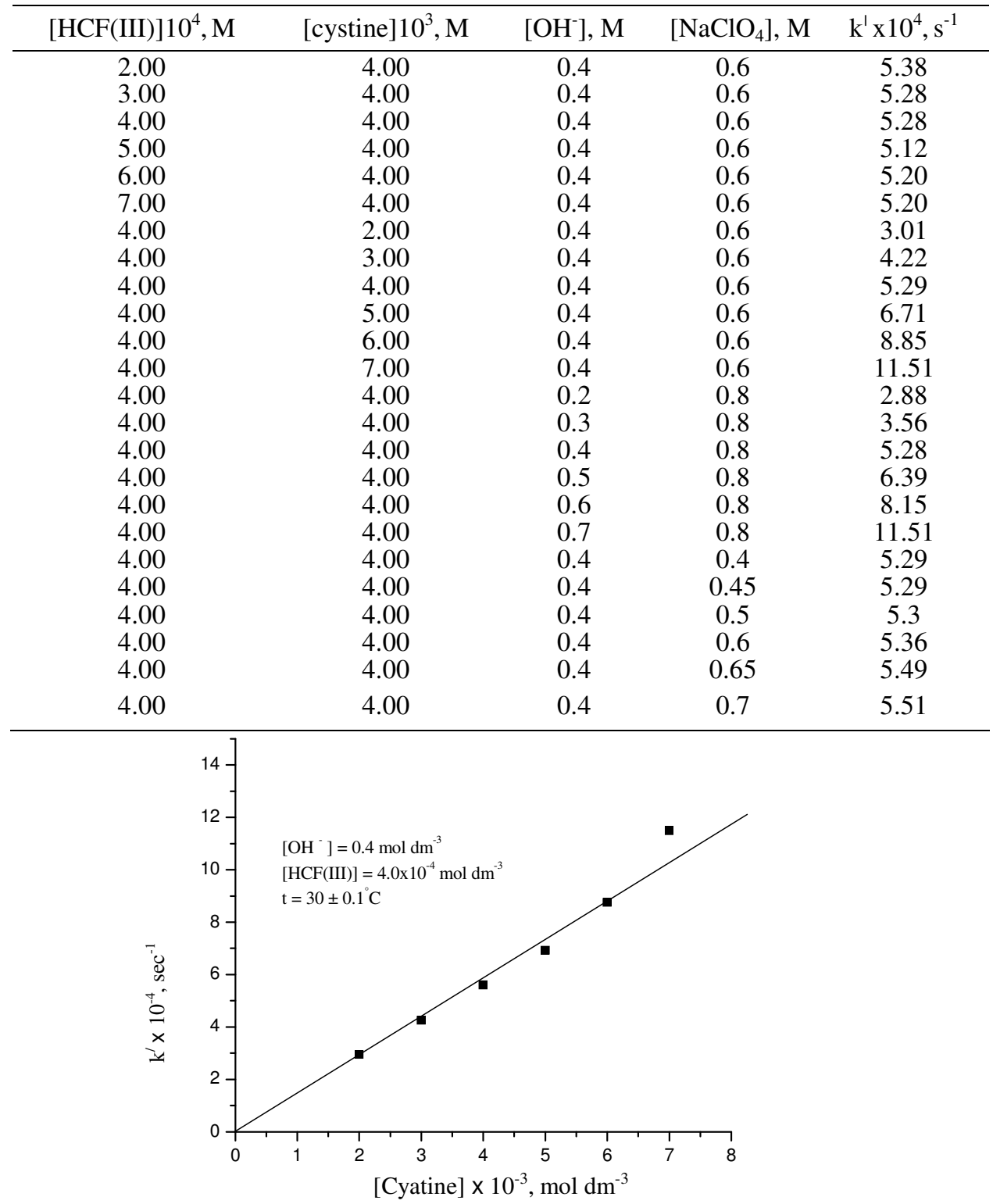

\section{Effect of temperature}

Figure 2. Order with respect to cystine

The effect of temperature on the rate of the reaction was studied by carrying out the reaction at four different temperatures $25,30,35$ and $40^{\circ} \mathrm{C}$ respectively. The plot of log k' versus $1 / \mathrm{T}$ was found to be linear indicating that the reaction obeys Arrhenius temperature dependence and the energy of activation, $E_{a}$ and entropy of activation, $\Delta S^{\#}$ were computed to be $62.3 \pm 2.0 \mathrm{kJmol}^{-1}$ and $-24.9 \pm 6.6 \mathrm{JK}^{-1} \mathrm{~mol}^{-1}$ respectively. 


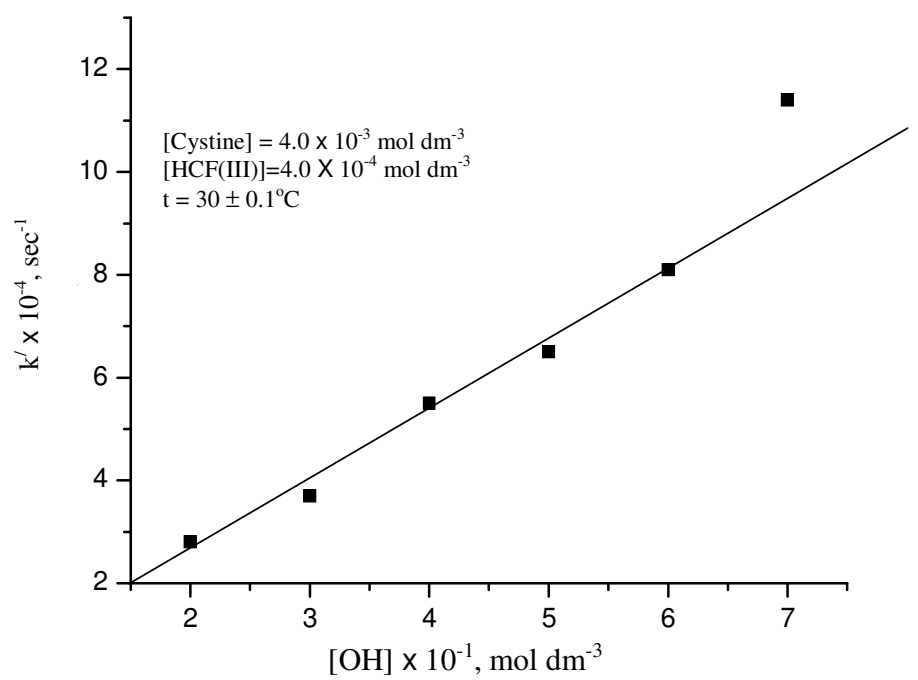

Figure 3. Order with respect to [alkali].

$L$-Cystine, $\left[-\mathrm{SCH}_{2} \mathrm{CH}\left(\mathrm{NH}_{2}\right) \mathrm{COOH}\right]_{2}$ is a sulfur containing amino acid and it possess four $\mathrm{pK}_{\mathrm{a}}$ values. Two corresponding to the carboxylic group $(\mathrm{COOH})_{1}=1.51,(\mathrm{COOH})_{2}$ $=2.79$ and the other two for amino group $\left(\mathrm{NH}_{3}{ }^{+}\right)_{1}=8.25,\left(\mathrm{NH}_{3}{ }^{+}\right)_{2}=8.97$. Hence, in $0.4 \mathrm{~mol} \mathrm{dm}^{-3}$ sodium hydroxide it exists as (cystine ${ }^{2-}$ ) to an extent of $99 \%$ and the remaining as (cystine $\left.{ }^{-}\right)$. Based on these observations, cystine ${ }^{2-}$ is presumed to be the reactive species and the following mechanism was proposed.

The reaction is first order with respect to each substrate and oxidant. Since the rate is not considerably affected by $\mathrm{HCF}(\mathrm{II})$, the probability of any fast equilibrium with the product preceding the rate determining step was ruled out. While in certain reactions complexation between hexacyanoferrate(III) and substrate was reported through cyanide ion displacement. Based on these observations the following mechanism was proposed.

$$
\begin{aligned}
& \text { cystine }^{2-}+\left[\mathrm{Fe}(\mathrm{CN})_{6}\right]^{3-} \underset{\text { slow }}{\stackrel{\mathrm{k}}{\longrightarrow}} \mathrm{X} \\
& \mathrm{X}+\left[\mathrm{Fe}(\mathrm{CN})_{6}\right]^{3-} \longrightarrow \text { Products } \\
& \text { in several fast steps }
\end{aligned}
$$

which leads to the rate equation

$$
\text { Rate }=\mathrm{k}\left[\text { cystine } \mathrm{e}^{2-}\right]\left[\mathrm{Fe}(\mathrm{CN})_{6}\right]^{3-}
$$

Since $\left[\right.$ cystine $\left.{ }^{2-}\right]=[\text { cystine }]_{\mathrm{t}}$ under the experimental conditions employed, as the reaction rate is first order dependent on $\left[\mathrm{OH}^{-}\right]$, the above equation can be written as

$$
\text { Rate }=\frac{-\mathrm{d}\left[\mathrm{Fe}(\mathrm{CN})_{6}^{3-}\right]}{\mathrm{dt}}=\mathrm{k}[\text { cystine }]_{\mathrm{t}}\left[\mathrm{OH}^{-}\right]\left[\mathrm{Fe}(\mathrm{CN})_{6}^{3-}\right]
$$

\section{Intimate mechanism}

$$
\begin{gathered}
-\mathrm{OOC}-\mathrm{CH}\left(\mathrm{NH}_{2}\right)-\mathrm{CH}_{2}-\mathrm{S}-\mathrm{S}-\mathrm{CH}_{2}-\mathrm{CH}\left(\stackrel{+}{\mathrm{NH}_{3}}\right)-\mathrm{COO}^{-}+\mathrm{OH}^{-} \stackrel{\mathrm{K}}{\left(\mathrm{RSSR}^{-}\right)} \\
-\mathrm{OOC}-\mathrm{CH}\left(\mathrm{NH}_{2}\right)-\mathrm{CH}_{2}-\mathrm{S}-\mathrm{S}-\mathrm{CH}_{2}-\mathrm{CH}\left(\mathrm{NH}_{2}\right)-\mathrm{COO}^{-} \\
\left(\mathrm{RSSR}^{2-}\right)
\end{gathered}
$$




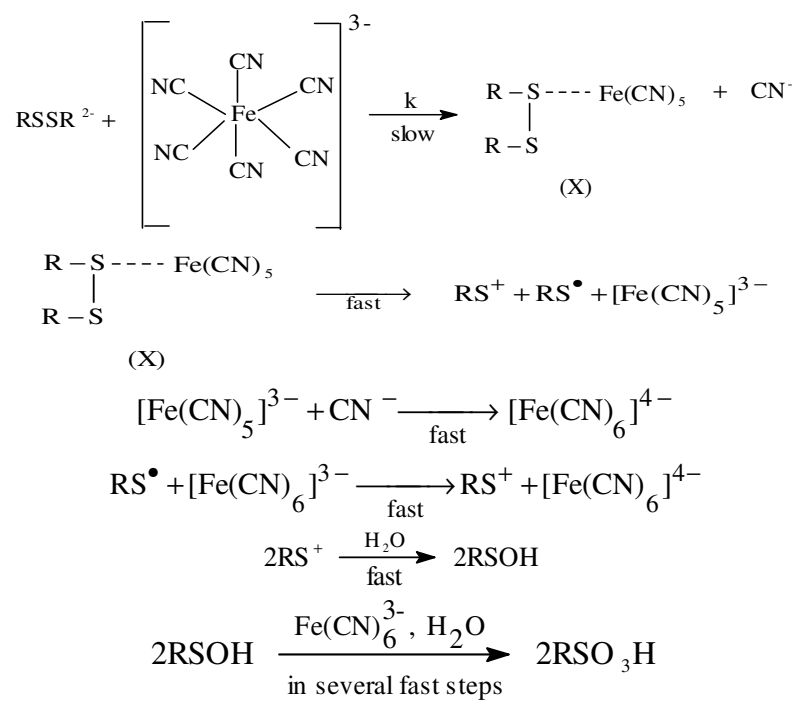

\section{References}

Scheme 1.

1. Shinohara K, J Biol Chem., 1931, XCVI(2), 285.

2. Kembhavi Md.Saleem R, Panari R G and Nandibewoor S T, Inorg React Mech., 1999, 1, 225.

3. Read J F, Bewic S A, Graves C R, Macpherson J M, Salah J C, Theriault A and Wyand A E H, Inorg Chim Acta., 2000, 303, 244.

4. Darkwa J, Oloja R, Chikwana E and Simoyi R H, J Phys Chem., A. 2004, 108, 5576.

5. Nagy P and Ashby M T, Chem Res Toxicol., 2005, 18, 919.

6. Kalyan Kumar A, Annapurna N and Vani P, Bull Chem Soc Ethiopia, 2008, 22(2).

7. Annapurna N, Kalyan Kumar A, Nageswara Rao G and Vani P J Indian Chem Soc.,2008, 8, 542.

8. Al-subu M M, Jondi W J, Amer A A, Hannoun M and Musmar M J, Chem heterocyclic Compounds, 2003, 39(4), 478

9. Mridula Sharma, Gayatri Sharma, Beena Agarwal, Khandelwal C L and Sharma P D Trans Met Chem., 2005, 30, 546.

10. Jose T P, Nandibewoor S T and Tuwar S M, J Solution Chem., 2006, 35(1), 51.

11. Al-Subu M M, Trans Met Chem., 2001, 26, 461.

12. Mulla R M, Hiremath G C and Nandibewoor S T, Monatshefte fur chemie., 2004, 135, 1489.

13. Mucientes A E, Poblete F J, Santiago F and Casado J, React Kinet Catal Lett., 1997, 62(2), 293.

14. Chimatadar S A, Salunke M S and Nandibewoor S T, Trans Met Chem., 2004, 29, 743.

15. Katafias A, Impert O, Kita P and Wrzeszcz G, Trans Met Chem., 2004, 29, 855.

16. Chimatadar S A, Koujalagi SB and Nandibewoor S T, Trans Met Chem., 2002, 27, 62

17. Tandon P K, Mehrotra A, Srivatsava M, Dhusia M and Singh S B, Trans Met Chem. 2007, 32, 74.

18. Dubey S, Sharma N, Khandalwal C L and Sharma P D, Trans Met Chem., 2003, 28, 176.

19. Mohan D, Chhabra V K and Gupta Y K, J Chem Soc Dalton Trans., 1975, 1737.

20. Hiremath G A, Timmanagoudar P L and Nandibewoor S T, React Kinet Catal Lett. 1998, 63(2), 403.

21. Dixit R S and Srivastava S N, Bull Inst Politech Iasi., 1977, 23(2), 29. 


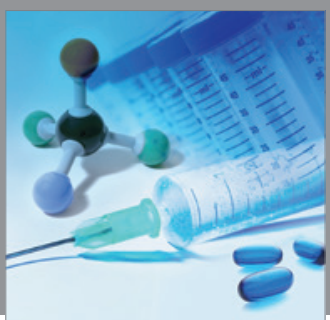

International Journal of

Medicinal Chemistry

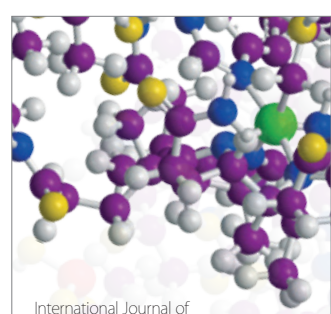

Carbohydrate Chemistry

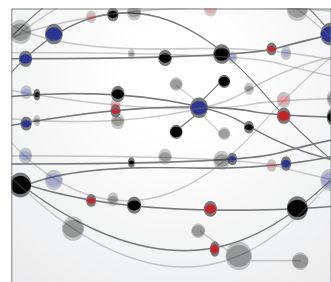

The Scientific World Journal
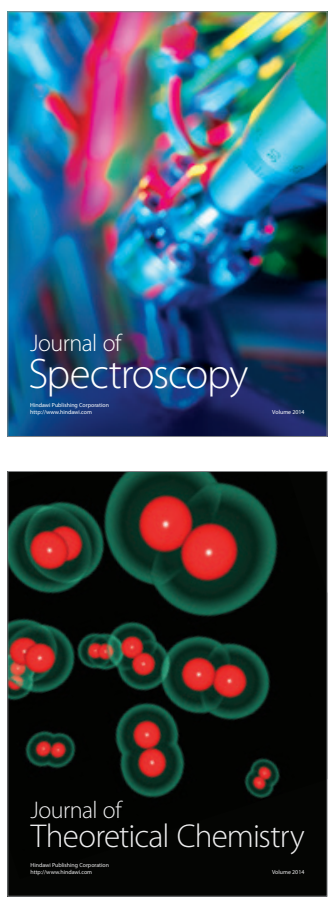
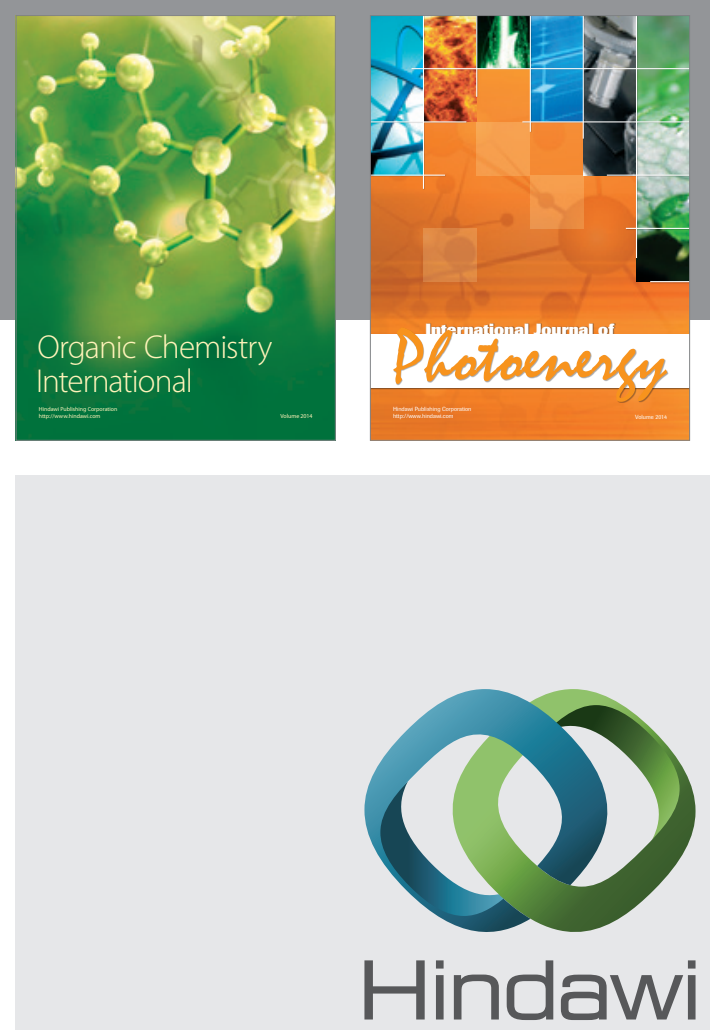

Submit your manuscripts at

http://www.hindawi.com
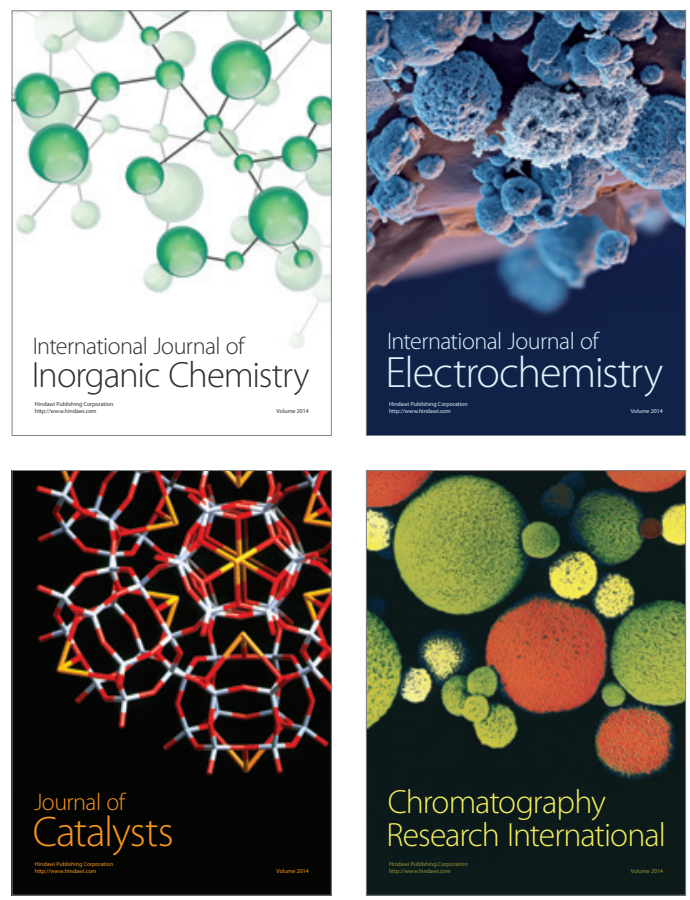
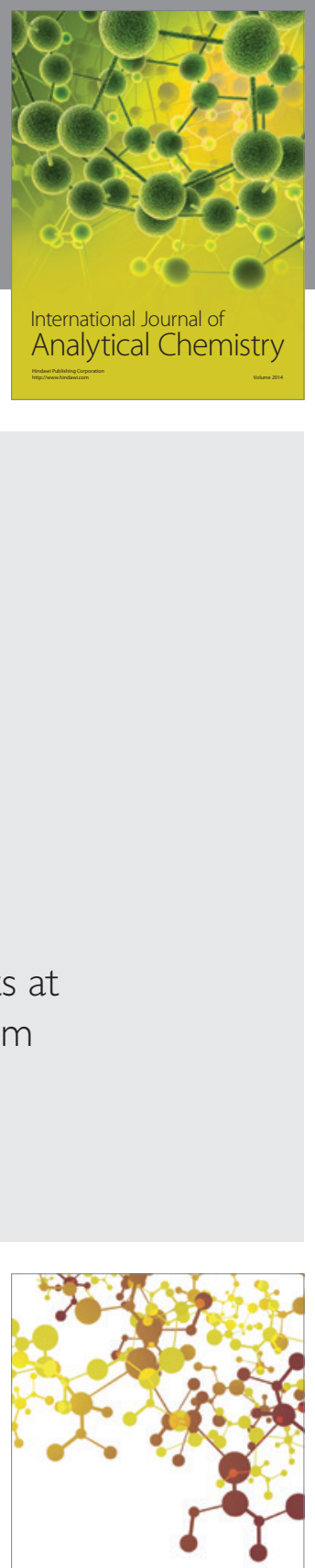

Journal of

Applied Chemistry
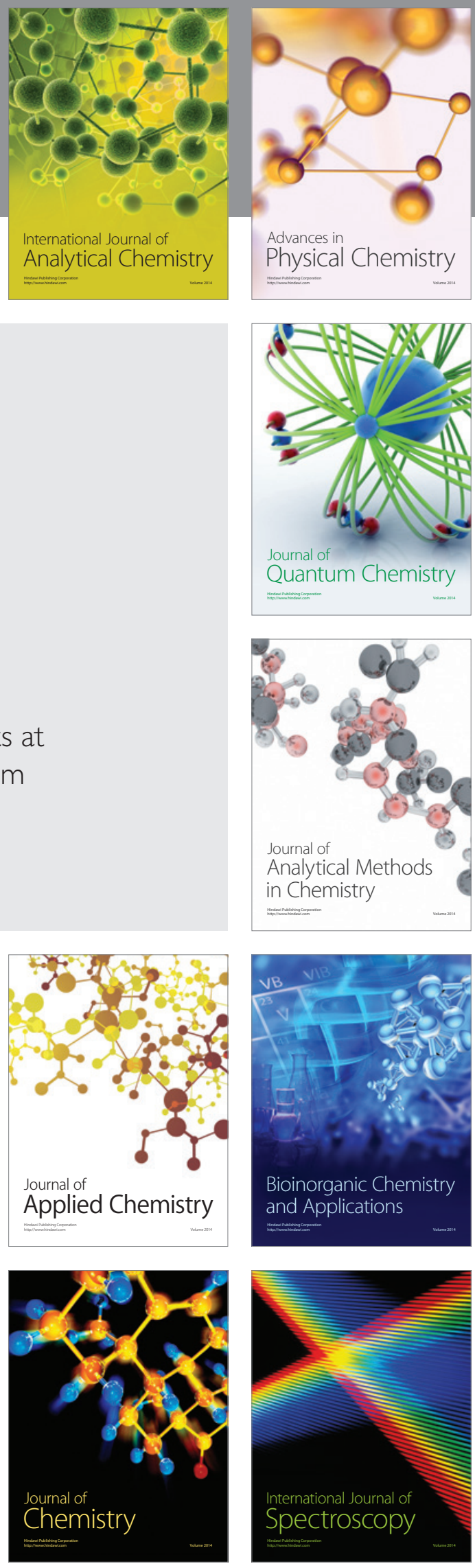